\title{
Hematopoietic Cell Transplantation for Inborn Errors of Immunity Other Than Severe Combined Immunodeficiency in Japan: Retrospective Analysis for 1985-2016
}

Satoshi Miyamoto

Tokyo Medical and Dental University

\section{Katsutsugu Umeda}

Tokyo Medical and Dental University

Mio Kurata

Daiko Minami, Higashi-ku, Nagoya

Masakatsu Yanagimachi

Tokyo Medical and Dental University

Akihiro Iguchi

Tokyo Medical and Dental University

Yoji Sasahara

Tokyo Medical and Dental University

Keiko Okada

Osaka City General Hospital

Takashi Koike

Tokai University School of Medicine

Reo Tanoshima

Yokohama City University Hospital

Masataka Ishimura

Kyushu University

Masafumi Yamada

Hokkaido University

Maho Sato

Murodocho, Izumi

Yoshiyuki Takahashi

Nagoya University Graduate School of Medicine

Michiko Kajiwara

Tokyo Medical and Dental University

Hiroshi Kawaguchi

Hiroshima University Graduate School of Biomedical \& Health Sciences

Masami Inoue 
Murodocho, Izumi

\section{Yoshiko Hashii}

Osaka University Graduate School of Medicine

Hiromasa Yabe

Tokyo Medical and Dental University

\section{Koji Kato}

Tokyo Medical and Dental University

\section{Yoshiko Atsuta}

Daiko Minami, Higashi-ku, Nagoya

\section{Kohsuke Imai ( $\square$ kimai.ped@tmd.ac.jp )}

Tokyo Medical and Dental University https://orcid.org/0000-0003-2132-8403

\section{Tomohiro Morio}

Tokyo Medical and Dental University

\section{Research Article}

Keywords: Inborn errors of immunity, hematopoietic cell transplantation, umbilical cord blood transplantation, retrospective study, Japan

Posted Date: May 27th, 2021

DOI: https://doi.org/10.21203/rs.3.rs-516749/v1

License: (c) (1) This work is licensed under a Creative Commons Attribution 4.0 International License. Read Full License

Version of Record: A version of this preprint was published at Journal of Clinical Immunology on January 4th, 2022. See the published version at https://doi.org/10.1007/s10875-021-01199-w. 


\section{Abstract}

Purpose

Hematopoietic cell transplantation (HCT) is a curative therapy for most patients with inborn errors of immunity (IEI). We conducted a nationwide study on HCT for patients with IEI other than severe combined immunodeficiency (non-SCID) in Japan.

Methods

Data from the Japanese national database (Transplant Registry Unified Management Program, TRUMP) for 567 patients with non-SCID IEl, who underwent their first HCT between 1985 and 2016, were retrospectively analyzed.

Results

The 10-year overall survival (OS) and event-free survival (EFS) was 74\% and 64\%, respectively. The 10-year OS for HCT from unrelated bone marrow (URBM), accounting for $39 \%$ of HCTs, was comparable to that for HCT from matched-sibling donor (MSD), being 79\% and 81\%, respectively. HCT from unrelated cord blood (URCB), accounting for $27 \%$ of HCTs, was also common, with a 10 -year OS of $69 \%$ but less robust engraftment. The intensity of conditioning was not associated with OS, hematologic recovery, or retransplantation incidence. Multivariate analyses of data on those receiving HCT during the 2006-2016 period revealed that respiratory impairment at HCT was associated with poor OS (hazard ratio [HR], 2.3; $P=$ $0.01)$ and that URCB $(\mathrm{HR}, 2.7 ; P=0.003)$ and related donor other than MSD $(\mathrm{HR}, 2.7 ; P=0.02)$ were associated with poor EFS.

\section{Conclusions}

We present the 1985-2016 status of HCT for non-SCID IEI in Japan with sufficient statistical power, highlighting the potential of URBM as an alternative donor and the substantial applicability of URCB. Detailed evaluation is needed for optimizing the HCT strategy for each IEI.

\section{Introduction}

Inborn errors of immunity (IEI) consist of heterogeneous hereditary disorders affecting various components of innate and acquired immunity including $T$ and $B$ lymphocytes, natural killer cells, phagocytes, macrophages, and complement proteins. Clinical manifestations of IEI are broad, such as susceptibility to serious or opportunistic infections, autoimmunity, autoinflammation, allergic diseases, lymphoproliferation, and malignancies. They are increasingly being defined owing to recent advances in genetics and molecular sciences. In the most recent classification by the International Union of Immunological Societies (IUIS), 416 diseases have been enrolled as IEI [1]. In the present scenario, the collective prevalence of IEI is estimated to be at least 1 in 1,000 to 5,000 [2]. 
Hematopoietic cell transplantation (HCT) was firstly performed for a patient with severe combined immunodeficiency (SCID) in 1968 [3]. Since then, HCT has been widely applied as a curative therapy for patients with IEI, especially for those with severe defects or dysregulation in cellular immunity. Unrelated cord blood (URCB) is commonly used in Japan and accounted for $33 \%$ of all allogenic HCTs during the period from 2009 to 2018 [4]. We previously performed a nationwide survey in Japan involving 88 patients with IEI who underwent unrelated cord blood transplantation (URCBT) and demonstrated an overall survival (OS) of $69 \%$ over 5 years [5]. However, no study has covered all HCTs for patients with IEl in Japan. Recently, we conducted a retrospective analysis of HCT for SCID in Japan. In this study, we conducted a nationwide retrospective analysis of HCT for patients with non-SCID IEI to provide an overview of the status and outcomes of HCTs and to develop strategies for HCT in Japan.

\section{Methods}

\section{Data Collection}

This study was approved by the Institutional Ethics Committee of Tokyo Medical and Dental University. The participants (and/or their guardians) provided written informed consents and were registered in the Transplant Registry Unified Management Program (TRUMP), an electronic database of all HCTs performed in Japan established by the Japanese Society for Transplantation and Cellular Therapy (JSTCT) [6]. The patients with non-SCID IEI who underwent their first HCT were included. The diagnoses of patients were collected according to the IUIS 2017 classification [7]. All transplant data were obtained from the TRUMP.

\section{Study Endpoints}

Event-free survival (EFS), defined as the period from HCT to death or retransplantation, was calculated to assess survival without graft failure. The diseases were classified into the following categories: combined immunodeficiency (CID; CD40 ligand deficiency, DOCK8 deficiency, ZAP-70 deficiency, bare lymphocyte syndrome, and unspecified CID), Wiskott-Aldrich syndrome (WAS), hemophagocytic syndrome (familial hemophagocytic lymphohistiocytosis (FHL), Chediak-Higashi syndrome, and X-linked lymphoproliferative disease), phagocytic disorder (chronic granulomatous disease [CGD], severe congenital neutropenia [SCN], leukocyte adhesion deficiency, Shwachman-Diamond syndrome, and GATA2 deficiency), and others (see Tables 1 and S1). The conditioning regimens were classified into myeloablative conditioning (MAC) and reduced-intensity conditioning (RIC). Regimens containing one of the following were classified as MAC; total-body irradiation at a total dose of $\geq 800 \mathrm{cGy}$, busulfan at a total dose of $\geq 12 \mathrm{mg} / \mathrm{kg}$, or melphalan at a total dose of $\geq 150 \mathrm{mg} / \mathrm{m}^{2}$, according to the Center for International Blood and Marrow Transplant Research criteria [8] and previous studies $[9,10]$. Other regimens were classified as RIC, including those in which the patient did not receive any chemotherapy or radiation. HLA matching was determined by serology for patients from the initial years and by genotype for those in the more recent years. We used the term "matched" to refer to those $8 / 8$, or $6 / 6$ matched and who lacked the HLA-C loci data, especially among patients from the initial years. The donor type was defined as follows: matched sibling donor (MSD), other related donor (ORD), URCB, and unrelated bone marrow (URBM). Neutrophil recovery was defined as the achievement of an absolute neutrophil count of $\geq 0.5 \times 10^{9} / \mathrm{L}$ for 3 consecutive days. Platelet recovery was 
defined as the achievement of an absolute platelet count of $\geq 50 \times 10^{9} / \mathrm{L}$ for 3 consecutive days, unsupported by transfusion for 7 days. The whole blood cell chimerism was evaluated from 100 days to 1.5 years after HCT and the patients who died before achieving neutrophil recovery were excluded. Chimerism was classified as follows: complete ( $\geq 95 \%$ donor chimerism), donor dominant ( $<95 \%$ and $\geq 80 \%$ donor chimerism), mixed ( $<80 \%$ and $\geq 20 \%$ donor chimerism), and low ( $<20 \%$ donor chimerism or patients who required retransplantation).

\section{Statistical Analysis}

OS and EFS were calculated using the Kaplan-Meier estimates, and Cox proportional hazard models were used to evaluate the impact of the independent risk factors on OS and EFS. Retransplantation, neutrophil recovery, platelet recovery, acute graft-versus-host disease (aGVHD), and chronic graft-versus-host disease (cGVHD) were analyzed using a cumulative incidence method. Death was considered as a competing event for retransplantation. Death and retransplantation were considered as competing events for neutrophil recovery, platelet recovery, aGVHD, and cGVHD. The cumulative incidence of cGVHD was calculated and was limited to the patients who survived more than 100 days after HCT. Gray's test was used for the comparisons of cumulative incidence, and the Fine-Gray model was used for evaluating the impact of independent risk factors on the cumulative incidence of retransplantation. For final models of multivariate analysis, respiratory impairment at HCT, donor type, and disease category were used as variables for OS and $\mathrm{EFS}$, and donor type and disease category were used for the incidence of retransplantation because these factors showed significance according to respective univariate analyses. We limited the patients to those who received HCT from 2006 onwards for multivariate analysis of OS and EFS, because during this period, the respiratory impairment at HCT was documented for most of the cases. The cumulative incidence, OS, EFS, and hazard ratios (HRs) are reported with $95 \%$ confidence intervals (Cls). All statistical analyses were performed using the Stata software v16.1 and EZR 1.42 [11]. Two-sided $p<0.05$ was considered significant. Data are presented as the median and range unless otherwise specified. All values enclosed in brackets represent $95 \% \mathrm{Cl}$.

\section{Results}

\section{Patient Characteristics}

A total of 567 patients with non-SCID IEl comprising 452 (80\%) males and $115(20 \%)$ females who underwent HCT between 1985 and 2016 were included in this study. The median duration of follow-up was 4.2 years ( 1 day -30.8 years). The characteristics of the participants are shown in Table $1 \mathrm{a}$, and the precise diagnoses are shown in Table 1b. The patients with CGD (126; 22\%), WAS (118; 21\%), FHL (101; 18\%), and $\operatorname{SCN}(60 ; 11 \%)$ were commonly underwent HCT. The patients received HCT at the age of 4 years $(0-64$ years) and the time from diagnosis to HCT was 1.7 years ( $0-36.8$ years). There was a significant difference in the interval between diagnosis and HCT according to disease category (hemophagocytic syndrome, 159 days [ 15 days -14.9 years]; WAS, 313 days [ 29 days -21.1 years]; CID, 750 days [33 days -18.8 years]; phagocytic disorder, 5.5 years [ 18 days -36.8 years]; $P<0.001$; Fig S1). Additionally, differences in various factors were observed between the disease categories (Table S1). 
The HCT from MSD accounted for 117 (21\%) cases. Among 376 (66\%) cases of HCT from unrelated donors, 157 (28\%) were URCB and 219 (39\%) were URBM. All URCBTs were a single unit. Among 61 (11\%) cases of HCT from ORD, 2 patients (CGD and CTLA4 deficiency) received post-transplant cyclophosphamide, and none received $\mathrm{TCRa}^{+} / \mathrm{CD} 19^{+}$depletion. The presence of respiratory impairment at HCT was observed in 41 (9\%) cases whereas active bacterial or fungal infection at HCT was noted in 95 (21\%) cases. There was a strong correlation between respiratory impairment and bacterial or fungal infection at HCT $(P<0.001)$.

Notably, more patients received RIC, tacrolimus, and URBM as a donor source than the others, and patients with phagocytic disorder received HCT more frequently than the other categories in the later period (Table S2).

\section{Overall Survival and Event-free Survival}

The summary of the transplant outcomes over the entire period is shown in Table 2. The OS and the EFS for 10 years were $74 \%$ [69-78\%] and 64\% [60-69\%], respectively. We did not observe any significant difference over time in OS or EFS (Fig. 1a, b).

There were significant differences in 10-year OS because of respiratory impairment at HCT $(61 \%$ [41\%-75\%] for patients with respiratory impairment vs. 78\% [73-83\%] for those without, Fig. 1c, $P=0.01$ ), but not because of bacterial or fungal infection at HCT, or because of conditioning (Fig. 1d, e). The HCT from bone marrow (BM) resulted in significantly better 10-year OS than that from cord blood (78\% [72-82\%] for BM vs. $68 \%[60-75 \%]$ for cord blood, Fig. 1f, $P<0.001)$. The HCT from MSD (81\% [72-87\%]) and URBM (79\% [71\%85\%]) led to similar 10-year OS, providing better survival than HCT from the other donor types (69\% [60$76 \%$ ] for URCB, and 56\% [41-68\%] for ORD, $P<0.001$, Fig. 1g). The patients with hemophagocytic syndrome (65\% [55-73\%]) had worse OS than those with other disease categories (Fig. 1h). We did not observe any statistical difference in OS according to HLA disparities in URBM, as well as in URCB (Fig. S2a, b). Additional survival curves in each disease category are shown in Fig S3 a-f. A similar OS was observed after HCT from MSD, URBM, and URCB in patients with WAS and phagocytic disorder, whereas a tendency for superior OS in the HCT from MSD was observed in patients with hemophagocytic syndrome. The intensity of the conditioning regimen did not show a significant difference in OS for any of the disease categories.

Multivariate analyses of data from the patients who received HCT from 2006 onwards (Table 3) revealed that respiratory impairment at HCT was associated with poor OS (HR: 2.3 [1.2-4.2]; $P=0.01$ ). URCB (HR: 2.7 [1.4-5.2]; $P=0.003$ ) and ORD (HR: 2.7 [1.2-6.1]; $P=0.02)$ were associated with poor EFS, but not with poor OS. Compared to the patients with WAS, those with hemophagocytic syndrome were associated with worse OS (HR: 3.1 [1.3-7.7]; $P=0.01$ ) and showed a weaker association with EFS. Patients with phagocytic disorder showed poor EFS (HR: 2.1 [1.04-4.4]; $\mathrm{P}=0.04$ ). As in univariate analyses, URBM did not show significant difference in impact for OS or EFS between MSD.

\section{Hematologic Recovery and Retransplantation}

Retransplantation was performed in 61 (11\%) cases with an interval of 177 days (20-2,945 days) from the first HCT. Only one patient with FHL and one with hyper IgE syndrome survived without retransplantation 
even though they did not achieve donor engraftment.

The HCT from MSD and URBM was associated with faster hematologic recovery than that from ORD or URCB (neutrophil recovery at day 60: $96 \%$ [90-98\%] for MSD vs. $98 \%$ [94-99\%] for URBM vs. $88 \%$ [76-94\%] for ORD vs. $82 \%$ [75-87\%] for URCB; Fig 2a; $P<0.001$; platelet recovery at day 60 : $85 \%$ [76-90\%] for MSD vs. $77 \%$ [70-82\%] for URBM vs. $59 \%$ [43-72\%] for ORD vs. $51 \%$ [43-58\%] for URCB; $P<0.001$; Fig. 2 b). The incidence of retransplantation was low for HCT from MSD or URBM (10-year: 11\% [5-18\%] for MSD vs. $6 \%$ [3-10\%] for URBM vs. $20 \%$ [10-31\%] for ORD vs. $21 \%$ [14-29\%] for URCB; $P<0.001$; Fig. S4a). HCT from URBM with two or more locus mismatches was associated with frequent retransplantation (10-year: 4\% [1$9 \%$ ] for matched URBM; $5 \%$ [1-12\%] for 1 mis URBM; $15 \%$ [5-30\%] for $\geq 2$ mis URBM; $P=0.04$; Fig. S2c). The HLA disparities in URCBT were associated with a tendency for higher incidence of retransplantation (Fig. S2d). Patients with hemophagocytic syndrome had slower hematologic recovery than those with other diseases (neutrophil recovery at day 60: 87\% [79-92\%]; $P=0.06$; Fig. 2c; platelet recovery at day 60: 63\% [54-71\%]; $P<0.001$; Fig. 2d); however, they did not show any significant difference in the cumulative incidence of retransplantation (Fig. S4b). Platelet recovery was faster in the patients who received RIC conditioning, although retransplantation was not correlated with the intensity of conditioning (Fig. $2 \mathrm{f}$, and Fig. S4c). We added the analyses for retransplantation in each disease category (Fig. S3 g-l), and found that URCBT was associated with a higher incidence of retransplantation in patients with hemophagocytic syndrome $(P=0.03)$ or phagocytic disorder $(P<0.001)$, but not in those with WAS. The intensity of conditioning regimen was not associated with any significant difference in the incidence of retransplantation in each of the disease categories.

Multivariate analysis revealed that URCB (HR: 3.8 [1.8-7.9]; $P<0.001)$, ORD (HR: $3.0[1.3-6.9] ; P=0.01)$, and phagocytic disorder (HR: 2.5 [1.2-5.1]; $P=0.02$ ), compared to WAS, were associated with an increased incidence of retransplantation (Table S3), as observed in the multivariate analysis for EFS.

\section{Chimerism}

More robust donor chimerism was achieved in patients who received HCT from MSD or URBM than in those who received HCT from ORD or URCB (Fig. S5a). The donor dominance in chimerism was not significantly different between MAC and RIC regimens (Fig. S5b). The HLA disparity in URBM or URCB, and disease category did not show a significant difference in terms of donor chimerism (data not shown).

\section{HCT-related Complications}

The cumulative incidence of aGVHD II-IV at 1 year was higher for HCT from URBM than for HCT from MSD (33\% [27-40\%] vs. $16 \%[10-23 \%], P=0.005$, Fig. $2 \mathrm{~g}$ ), and cGVHD at 2 years was more frequent in HCT from ORD than in HCT from MSD (33\% [20-46\%] vs. $15 \%$ [9-22\%], $P=0.01$, Fig. $2 \mathrm{~h})$. The cumulative incidence of GVHD in URCBT was 24\% [17-31\%] for aGVHD II-IV at 1 year and 13\% [8-20\%] for cGVHD at 2 years, which did not show a statistical difference when compared to that in HCT from MSD. The HLA disparities in URBM or URCB were not significantly associated with the incidence of GVHD (Fig. S2e-h). 
Other HCT-related complications are shown in Table 4. Among the patients evaluated, viral and fungal infection was observed in $21 \%$ and $12 \%$, respectively. URCBT was significantly associated with a higher incidence of post-HCT bacterial infection $(P=0.03)$, but not with post-HCT viral infection (Table S4). In terms of long-term toxicities, $14(3 \%)$ patients developed malignancy, most of which were associated with post-transplant lymphoproliferation. Short stature was most commonly seen, occurring in $19 \%$ of the patients. We did not observe statistical association of MAC regimens and the incidence of these complications (data not shown).

\section{Cause of Death}

Death from infection was the most common, accounting for 43 (33\%) cases (Table 5). Among the patients who died, MAC regimen was commonly associated with death from infection $(P=0.0496$, Table S5). The donor type or disease category was not correlated with differences in the cause of death (data not shown).

\section{Discussion}

Our results show a 10 -year OS of $74 \%$ for patients with non-SCID IEI, who underwent their first HCT between 1985 and 2016, which is comparable to that from multicenter studies in other countries (Europe, $69 \%$ over 10 years [12]; Australia and New Zealand, 72\% over 5 years [13]; Brazil, 72\% over 5 years [14]; Colombia, $62 \%$ over 5 years [15]).

We demonstrated the effect of URBM and URCB on the outcome of HCT for non-SCID IEl in Japan. The HCT from URBM was the most frequently performed, showing comparable 10-year OS to that for HCT from MSD (79\% vs $81 \%$, respectively). The equivalent outcome for HCT from URBM and MSD has also been reported from other countries [12,13]. Although the incidence of aGVHD was high with HCT from URBM, the excellent survival was partly due to robust hematologic recovery, low retransplantation incidence, and sufficient donor chimerism. The preparation for HCT from URBM takes several months in Japan and is not suitable for urgent transplantation, but our analysis reconfirms that URBM can be considered as a useful alternative donor source for stable patients who have enough time to prepare for HCT.

The OS for URCBT over 10 years was $69 \%$. Although the OS was inferior to that for HCT from MSD, this might be acceptable for patients who require urgent transplantation and do not have MSD. A similar incidence of GVHD in URCBT and HCT from MSD also suggested its utility in Japan. However, the engraftment after URCBT was not robust, as evident from a slow hematologic recovery, high retransplantation incidence, and low donor chimerism. Furthermore, multivariate analyses demonstrated that URCB was an independent risk for poor EFS and retransplantation. Although URCBT for SCID patients in Japan showed excellent outcome, including OS, hematologic recovery, and stable engraftment [submitted], the disadvantage for engraftment is well known in the HCT for hematologic disorders other than SCID [1620]. Despite the ready availability and feasibility of URCBT, we recognize the risk for poor engraftment for non-SCID IEl as a whole.

For patients who received HCT from ORD, we observed a poor OS/EFS, as well as poor engraftment and a high incidence of cGVHD. In our cohort, post-transplant cyclophosphamide or TCRa $\beta^{+} / \mathrm{CD} 19^{+}$depletion, 
which are beginning to be adopted in haploidentical HCTs for IEls worldwide [21-26] as well as in Japan [27], was not used in most of the cases. The introduction of these novel techniques can expectedly help exploit more available donors and also improve the outcome of HCT from ORD in the coming decades. Furthermore, gene therapy (GT) for numerous IEls, including SCID, WAS, CGD, and leukocyte adhesion deficiency, is being developed [28]. Promising results for these novel approaches should improve the prognosis of IEl patients without suitable donors.

We analyzed the association of conditioning regimens and the outcomes of HCT. In the recent decade, RIC regimens have been commonly chosen. The OS, retransplantation incidence, and donor chimerism for RIC regimens were not significantly different from those for MAC regimens, indicating sufficient efficacy of RIC regimens. This was also true in the analysis for each disease category. Although we did not observe a difference in HCT-related complications between the two regimens, MAC regimens were more commonly associated with death from infection; and we speculate that strong tissue injury associated with MAC, such as mucosal damage, probably contributed to it. RIC regimens potentially reduce short- and/or long-term conditioning-related toxicities and are considered suitable in HCT for IEI.

We also demonstrate that respiratory impairment at HCT was an independent risk for OS. The strong association between respiratory impairment and infection implied that the infection was responsible for dyspnea in most of the patients. Unlike for SCID patients in western countries $[10,12]$ and Japan [submitted], the presence of infection alone was not associated with poor survival, but infection and subsequent pulmonary damage could be a risk. The management of non-infectious manifestations is equally important as the control of infectious events before HCT. For instance, it is well known that the remission status of hemophagocytic syndrome is associated with good survival after HCT [29,30]. Several targeted therapies have been developed for IEl in recent years, such as anti-interferon-y antibody for hemophagocytic lymphohistiocytosis [31], JAK inhibitor for hemophagocytic lymphohistiocytosis [32], or STAT1 or STAT3 gain-of-function [33], CTLA4-Fc fusion protein for CTLA4 haploinsufficiency [34] or LRBA deficiency [35], and $\mathrm{PI3K}$ inhibitor for activated PI3K $\delta$ syndrome [36]. Those novel pharmacological treatments are expected to control the disease activity as bridging therapies before HCT.

Besides the results for non-SCID IEI as a whole, IEI comprises heterogeneous diseases and each disorder is associated with a different background of the patients (Fig. S1 and Table S1) or outcome of HCT (Fig. S3). In patients with WAS, the similar outcomes for URBM and MSD confirmed that URBM was preferable as an alternative donor. We also show that OS or incidence of retransplantation after URCBT for WAS patients was not different from that for HCT from MSD, suggesting the potential of URCB as a candidate donor as well. The availability of URCB for WAS patients was consistent with the finding from studies from western countries $[37,38]$. Busulfan-based RIC regimen is effective for WAS patients in terms of survival and donor engraftment [37], and our results are consistent with this finding.

The interval between diagnosis and HCT was the shortest for patients with hemophagocytic syndrome compared with that for patients with other diseases, indicating the urgency for HCT. URCB was the most commonly chosen for these diseases probably owing to rapid availability. The 10-year OS for URCBT was $58 \%$, which was similar to that reported from Europe [39] and Japan [40]; however, it was not satisfactorily 
compared to the 10-year OS for HCT from MSD (79\%), and the incidence of retransplantation was higher in URCBT than for HCT from MSD. Further approaches, including optimal conditioning regimen, exploring indication of haplo-HCT with post-transplant cyclophosphamide [41], or better pre-HCT disease control using molecular-targeted therapies [31,32], would be necessary for improving the management of HCT in the coming decades.

In patients with phagocytic disorder, the outcome for HCT from URBM and MSD was equivalent. Moreover, this disease category showed a risk for retransplantation as well as poor EFS, and URCBT for these diseases showed a significant risk for retransplantation. The patients were more commonly complicated with infection or respiratory impairment at HCT (Table S1), which may also pose a risk for infection, concerning poor engraftment in URCBT. URCBT for CGD patients is reported to have poor engraftment in studies from Japan [42] and European countries [43], which is consistent with our results. Because the time between diagnosis and HCT was relatively long and urgent HCT is considered rare, URCB may be used for these diseases only on limited occasions. We also observed the non-inferiority of the RIC regimen to MAC regimen for phagocytic disorders. Recently, the prospective clinical trials have shown that a fludarabine/busulfanbased RIC regimen is effective in CGD patients $[44,45]$. To reduce regimen-related toxicity, especially in recipients with concomitant infection, RIC is recommended for these diseases.

We provided some insights for preferred management of HCT for some disease categories. To establish a better disease-specific management, it is important to conduct a precise evaluation for each disease through retrospective analyses, or possibly through prospective studies. Moreover, novel therapeutic modalities including GVHD prophylaxis, GT, or molecular targeted approaches are being established with a sufficient number of patients, requiring revision of the current strategies for each IEI.

Our study has several limitations. First, some important information, such as precise genotype of the diseases was not available in the TRUMP registry for the patients who received HCT in the earlier period, which might have reduced the sample size and affected the analyses. Second, the TRUMP registry was not oriented for the HCT for IEl; some disease-specific complications that might affect the outcome of HCT were missing (e.g., colitis for WAS, CGD, or XIAP deficiency, and autoimmunity for WAS or CTLA4 haploinsufficiency). The data of immunologic reconstitution after HCT, such as lineage specific chimerism or discontinuation of immunoglobulin were also unavailable. Third, a precise analysis of each disease was not performed. For further detailed analysis, we have already published retrospective studies for each IEI from Japan $[42,46,47]$ and will also perform such studies for other diseases in the future on behalf of the Hereditary Disorder Working Group of the JSTCT, collaborating with the Primary Immunodeficiency Database in Japan [48] and the TRUMP.

In conclusion, we present an overview of the backgrounds and outcome of HCT for non-SCID IEls in Japan with a large number of patients for sufficient statistical power. We demonstrate that the OS for HCT from URBM and MSD was almost equivalent in Japan, confirming URBM as an alternative donor source in HCT for non-SCID IEI. URCBT, which was also commonly performed in Japan, showed substantial applicability for some diseases but has a high risk for poor engraftment. We also demonstrate the efficacy of RIC regimens and highlight the importance of disease control before HCT. These results should contribute to the 
development of future management strategies for IEls in Japan. Furthermore, detailed evaluation for individual IEI, along with recent advances in novel therapeutic approaches, needs to be addressed for establishing an optimal HCT strategy for each disease.

\section{Abbreviations}

aGVHD Acute graft-versus-host disease

BM Bone marrow

CGD Chronic granulomatous disease

cGVHD Chronic graft-versus-host disease

$\mathrm{Cl}$ Confidence interval

CID Combined immunodeficiency

EFS Event-free survival

FHL Familial hemophagocytic lymphohistiocytosis

GVHD Graft-versus-host disease

GT Gene therapy

HCT Hematopoietic cell transplantation

HR Hazard ratio

IEl Inborn errors of immunity

IUIS International Union of Immunological Societies

JSTCT Japanese Society for Transplantation and Cellular Therapy

MAC Myeloablative conditioning

MSD Matched sibling donor

ORD Other related donor

OS Overall survival

PB Peripheral blood

RIC Reduced-intensity conditioning 
SCID Severe combined immunodeficiency

SCN Severe congenital neutropenia

TRUMP Transplant Registry Unified Management Program

URBM Unrelated bone marrow

URCB Unrelated cord blood

URCBT Unrelated cord blood transplantation

WAS Wiskott-Aldrich syndrome

\section{Declarations}

Funding: This work was supported by the Japanese Ministry of Health, Labor, and Welfare [grant number 20FC1053], and Japan Agency for Medical Research and Development [grant numbers JP19|k0201100 and JP19gk0110041].

Conflicts of interest/Competing interests: All authors declare that there are no conflicts of interest to disclose concerning this study.

Ethics approval: The studies involving human participants were reviewed and approved by the Institutional Review Boards at the Japanese Society for Transplantation and Cellular Therapy (JSTCT) and Tokyo Medical and Dental University.

Consent to participate/publication: All participants (and/or their guardians) provided written informed consent for research use of their data and publication.

Availability of data and material: The datasets presented in this article are not readily available because they belong to the JSTCT and the Japanese Data Center for Hematopoietic Cell Transplantation (JDCHCT). Requests to access the datasets should be directed to http://www.jdchct.or.jp/.

Code availability: All statistical analyses were performed using the Stata software v16.1 and EZR 1.42.

\section{Acknowledgment}

We thank the Japan Marrow Donor Program, the cord blood banks in Japan, and the staff at the participating hospitals who attended to the patients and provided information for the TRUMP registry. We also thank Soichi Adachi, Shunichi Kato, Yasuo Horikoshi, Miharu Yabe, Nao Yoshida, Hiromitsu Takakura, Sae Ishimaru, Shinya Osone, Hidetoshi Takada, Nozomu Kawashima, Shinobu Tamura, Ayako Yamamori, Koji Kawaguchi, Akira Nishimura, Risa Matsumura, and Takako Miyamura, who supported this study as members of the Hereditary Disorder Working Group of the Japanese Society for Transplantation and Cellular Therapy. 


\section{AUTHOR CONTRIBUTION}

SM designed the research, analyzed the data, and wrote the manuscript. $\mathrm{KU}, \mathrm{MYan}, \mathrm{Al}, \mathrm{YS}, \mathrm{HY}$, and KK revised the manuscript. MKu and YA verified the analytical method and analyzed the data. KO, TK, RT, MI, MYam, MS, YT, MKa, and HK recruited the patients and collected the data. $\mathrm{MI}, \mathrm{YH}$, and $\mathrm{KK}$ contributed to transplantation data management as members of the Japanese Data Center for Hematopoietic Cell Transplantation. $\mathrm{KI}$ and TM designed the research and revised the manuscript. All authors contributed to the article and approved the submitted version.

\section{References}

1. Tangye SG, Al-Herz W, Bousfiha A, Chatila T, Cunningham-Rundles C, Etzioni A, et al. Human inborn errors of immunity: 2019 Update on the classification from the International Union of Immunological Societies Expert Committee. J Clin Immunol. 2020;40:24-64. https://doi.org/10.1007/s10875-01900737-x.

2. Zhang Q, Frange P, Blanche S, Casanova JL. Pathogenesis of infections in HIV-infected individuals: insights from primary immunodeficiencies. Curr Opin Immunol. 2017;48:122-33. https://doi.org/10.1016/j.coi.2017.09.002.

3. Gatti RA, Meuwissen HJ, Allen HD, Hong R, Good RA. Immunological reconstitution of sex-linked lymphopenic immunological deficiency. Lancet. 1968;2:1366-9. https://doi.org/10.1016/s01406736(68)92673-1.

4. Hematopoietic Cell Transplantation in Japan. Annual Report of Nationwide Survey 2019. The Japanese Data Center for Hematopoietic Cell Transplantation/The Japan Society for Hematopoietic Cell Transplantation. Available at:http://www.jdchct.or.jp/data/report/2019/2-10-2.pdf. Accessed December 23, 2020.

5. Morio T, Atsuta Y, Tomizawa D, Nagamura-Inoue T, Kato K, Ariga T, et al. Outcome of unrelated umbilical cord blood transplantation in 88 patients with primary immunodeficiency in Japan. $\mathrm{Br} \mathrm{J}$ Haematol. 2011;154:363-72. https://doi.org/10.1111/j.1365-2141.2011.08735.x.

6. Atsuta Y, Suzuki R, Yoshimi A, Gondo H, Tanaka J, Hiraoka A, et al. Unification of hematopoietic stem cell transplantation registries in Japan and establishment of the TRUMP System. Int J Hematol. 2007;86:269-74. https://doi.org/10.1532/IJH97.06239.

7. Bousfiha A, Jeddane L, Picard C, Ailal F, Gaspar HB, Al-Herz W, et al. The 2017 IUIS phenotypic classification for primary immunodeficiencies. J Clin Immunol. 2018;38:129-43. https://doi.org/10.1007/s10875-017-0465-8.

8. Bacigalupo A, Ballen K, Rizzo D, Giralt S, Lazarus H, Ho V, et al. Defining the intensity of conditioning regimens: working definitions. Biol Blood Marrow Transplant. 2009;15:1628-33. https://doi.org/10.1016/j.bbmt.2009.07.004.

9. Pai S-Y, Logan BR, Griffith LM, Buckley RH, Parrott RE, Dvorak CC, et al. Transplantation outcomes for severe combined immunodeficiency, 2000-2009. N Engl J Med. 2014;371:434-46. https://doi.org/10.1056/NEJMoa1401177. 
10. Haddad E, Logan BR, Griffith LM, Buckley RH, Parrott RE, Prockop SE, et al. SCID genotype and 6-month posttransplant CD4 count predict survival and immune recovery. Blood. 2018;132:1737-49. https://org/10.1182/blood-2018-03-840702.

11. Kanda Y. Investigation of the freely available easy-to-use software 'EZR' for medical statistics. Bone Marrow Transplant. 2013;48:452-8. https://doi.org/10.1038/bmt.2012.244.

12. Gennery AR, Slatter MA, Grandin L, Taupin P, Cant AJ, Veys P, et al. Transplantation of hematopoietic stem cells and long-term survival for primary immunodeficiencies in Europe: entering a new century, do we do better? J Allergy Clin Immunol. 2010;126:602-10. https://doi.org/10.1016/j.jaci.2010.06.015.

13. Mitchell R, Nivison-Smith I, Anazodo A, Tiedemann K, Shaw P, Teague L, et al. Outcomes of hematopoietic stem cell transplantation in primary immunodeficiency: a report from the Australian and New Zealand Children's Haematology Oncology Group and the Australasian Bone Marrow Transplant Recipient Registry. Biol Blood Marrow Transplant. 2013;19:338-43.

https://doi.org/10.1016/j.bbmt.2012.11.619.

14. Fernandes JF, Nichele S, Daudt LE, Tavares RB, Seber A, Kerbauy FR, et al. Transplantation of hematopoietic stem cells for primary immunodeficiencies in Brazil: Challenges in treating rare diseases in developing countries. J Clin Immunol. 2018;38:917-26. https://doi.org/10.1007/s10875-018-0564-1.

15. Olaya M, Franco A, Chaparro M, Estupiñan M, Aristizabal D, Builes-Restrepo N, et al. Hematopoietic stem cell transplantation in children with inborn errors of immunity: a multi-center experience in Colombia. J Clin Immunol. 2020;40:1116-23. https://doi.org/10.1007/s10875-020-00856-w.

16. Eapen M, Rocha V, Sanz G, Scaradavou A, Zhang M-J, Arcese W, et al. Effect of graft source on unrelated donor haemopoietic stem-cell transplantation in adults with acute leukaemia: a retrospective analysis. Lancet Oncol. 2010;11:653-60. https://doi.org/10.1016/S1470-2045(10)70127-3.

17. Laughlin MJ, Eapen M, Rubinstein P, Wagner JE, Zhang M-J, Champlin RE, et al. Outcomes after transplantation of cord blood or bone marrow from unrelated donors in adults with leukemia. $\mathrm{N}$ Engl $\mathrm{J}$ Med. 2004;351:2265-75. https://doi.org/10.1056/NEJMoa041276.

18. Peffault de Latour R, Purtill D, Ruggeri A, Sanz G, Michel G, Gandemer V, et al. Influence of nucleated cell dose on overall survival of unrelated cord blood transplantation for patients with severe acquired aplastic anemia: a study by eurocord and the aplastic anemia working party of the European group for blood and marrow transplantation. Biol Blood Marrow Transplant. 2011;17:78-85. https://doi.org/10.1016/j.bbmt.2010.06.011.

19. Rocha V, Labopin M, Sanz G, Arcese W, Schwerdtfeger R, Bosi A, et al. Transplants of umbilical-cord blood or bone marrow from unrelated donors in adults with acute leukemia. N Engl J Med. 2004;351:2276-85. https://doi.org/10.1056/NEJMoa041469.

20. Ruggeri A, Eapen M, Scaravadou A, Cairo MS, Bhatia M, Kurtzberg J, et al. Umbilical cord blood transplantation for children with thalassemia and sickle cell disease. Biol Blood Marrow Transplant. 2011;17:1375-82. https://doi.org/10.1016/j.bbmt.2011.01.012.

21. Kurzay M, Hauck F, Schmid I, Wiebking V, Eichinger A, Jung E, et al. T-cell replete haploidentical bone marrow transplantation and post-transplant cyclophosphamide for patients with inborn errors. Haematologica. 2019;104:e478-82. https://doi.org/10.3324/haematol.2018.215285. 
22. Neven B, Diana J-S, Castelle M, Magnani A, Rosain J, Touzot F, et al. Haploidentical hematopoietic stem cell transplantation with post-transplant cyclophosphamide for primary immunodeficiencies and inherited disorders in children. Biol Blood Marrow Transplant. 2019;25:1363-73.

https://doi.org/10.1016/j.bbmt.2019.03.009.

23. Uppuluri R, Sivasankaran M, Patel S, Swaminathan VV, Ramanan KM, Ravichandran N, et al. Haploidentical stem cell transplantation with post-transplant cyclophosphamide for primary immune deficiency disorders in children: Challenges and outcome from a tertiary care center in South India. J Clin Immunol. 2019;39:182-7. https://doi.org/10.1007/s10875-019-00600-z.

24. Balashov D, Shcherbina A, Maschan M, Trakhtman P, Skvortsova Y, Shelikhova L, et al. Single-center experience of unrelated and haploidentical stem cell transplantation with TCRaß and CD19 depletion in children with primary immunodeficiency syndromes. Biol Blood Marrow Transplant. 2015;21:1955-62. https://doi.org/10.1016/j.bbmt.2015.07.008.

25. Elfeky R, Shah RM, Unni MNM, Ottaviano G, Rao K, Chiesa R, et al. New graft manipulation strategies improve the outcome of mismatched stem cell transplantation in children with primary immunodeficiencies. J Allergy Clin Immunol. 2019;144:280-93. https://doi.org/10.1016/j.jaci.2019.01.030.

26. Shah RM, Elfeky R, Nademi Z, Qasim W, Amrolia P, Chiesa R, et al. T-cell receptor aß+ and CD19+ celldepleted haploidentical and mismatched hematopoietic stem cell transplantation in primary immune deficiency. J Allergy Clin Immunol. 2018;141:1417-26. https://doi.org/10.1016/j.jaci.2017.07.008.

27. Osumi T, Yoshimura S, Sako M, Uchiyama T, Ishikawa T, Kawai T, et al. Prospective study of allogeneic hematopoietic stem cell transplantation with post-transplantation cyclophosphamide and antithymocyte globulin from HLA-mismatched related donors for nonmalignant diseases. Biol Blood Marrow Transplant. 2020;26:e286-91. https://doi.org/10.1016/j.bbmt.2020.08.008.

28. Fischer A, Hacein-Bey-Abina S. Gene therapy for severe combined immunodeficiencies and beyond. J Exp Med. 2020;217:e20190607. https://doi.org/10.1084/jem.20190607.

29. Horne A, Janka G, Maarten Egeler R, Gadner H, Imashuku S, Ladisch S, et al. Haematopoietic stem cell transplantation in haemophagocytic lymphohistiocytosis. Br J Haematol. 2005;129:622-30. https://doi.org/10.1111/j.1365-2141.2005.05501.x.

30. Ouachée-Chardin M, Elie C, de Saint Basile G, Le Deist F, Mahlaoui N, Picard C, et al. Hematopoietic stem cell transplantation in hemophagocytic lymphohistiocytosis: a single-center report of 48 patients. Pediatrics. 2006;117:e743-50. https://doi.org/10.1542/peds.2005-1789.

31. Locatelli F, Jordan MB, Allen C, Cesaro S, Rizzari C, Rao A, et al. Emapalumab in children with primary hemophagocytic lymphohistiocytosis. N Engl J Med. 2020;382:1811-22. https://doi.org/10.1056/NEJMoa1911326.

32. Ramanan KM, Uppuluri R, Ravichandran N, Patel S, Swaminathan VV, Jayakumar I, et al. Successful remission induction in refractory familial hemophagocytic

33. Iymphohistiocytosis with ruxolitinib as a bridge to hematopoietic stem cell transplantation. Pediatr Blood Cancer. 2020;67:e28071. https://doi.org/10.1002/pbc.28071.Forbes LR, Vogel TP, Cooper MA, Castro-Wagner J, Schussler E, Weinacht KG, et al. Jakinibs for the treatment of immune dysregulation in 
patients with gain-of-function signal transducer and activator of transcription 1 (STAT1) or STAT3 mutations. J Allergy Clin Immunol. 2018;142:1665-9. https://doi.org/10.1016/j.jaci.2018.07.020.

34. Schwab C, Gabrysch A, Olbrich P, Patiño V, Warnatz K, Wolff D, et al. Phenotype, penetrance, and treatment of 133 cytotoxic T-lymphocyte antigen 4-insufficient subjects. J Allergy Clin Immunol. 2018;142:1932-46. https://doi.org/10.1016/j.jaci.2018.02.055.

35. Lo B, Zhang K, Lu W, Zheng L, Zhang Q, Kanellopoulou C, et al. Patients with LRBA deficiency show CTLA4 loss and immune dysregulation responsive to abatacept therapy. Science. 2015;349:436-40. https://doi.org/10.1126/science.aaa1663.

36. Rao VK, Webster S, Dalm VASH, Šedivá A, van Hagen PM, Holland S, et al. Effective "activated PI3Kס syndrome"-targeted therapy with the PI3Kס inhibitor leniolisib. Blood. 2017;130:2307-16. https://doi.org/10.1182/blood-2017-08-801191.

37. Burroughs LM, Petrovic A, Brazauskas R, Liu X, Griffith LM, Ochs HD, et al. Excellent outcomes following hematopoietic cell transplantation for Wiskott-Aldrich syndrome: a PIDTC report. Blood. 2020;135:2094-105. https://doi.org/10.1182/blood.2019002939.

38. Shekhovtsova Z, Bonfim C, Ruggeri A, Nichele S, Page K, AlSeraihy A, et al. A risk factor analysis of outcomes after unrelated cord blood transplantation for children with Wiskott-Aldrich syndrome. Haematologica. 2017;102:1112-9. https://doi.org/10.3324/haematol.2016.158808.

39. Furtado-Silva JM, Paviglianiti A, Ruggeri A, Boelens JJ, Veys P, Ahmari AA, et al. Risk factors affecting outcome of unrelated cord blood transplantation for children with familial haemophagocytic lymphohistiocytosis. Br J Haematol. 2019;184:397-404. https://doi.org/10.1111/bjh.15642.

40. Ohga S, Kudo K, Ishii E, Honjo S, Morimoto A, Osugi Y, et al. Hematopoietic stem cell transplantation for familial hemophagocytic lymphohistiocytosis and Epstein-Barr virus-associated hemophagocytic lymphohistiocytosis in Japan. Pediatr Blood Cancer. 2010;54:299-306. https://doi.org/10.1002/pbc.22310.

41. Neven B, Diana JS, Castelle M, Magnani A, Rosain J, Touzot F, et al. Haploidentical hematopoietic stem cell transplantation with post-transplant cyclophosphamide for primary immunodeficiencies and inherited disorders in children. Biol Blood Marrow Transplant. 2019;25:1363-73. https://doi.org/10.1016/j.bbmt.2019.03.009.

42. Yanagimachi M, Kato K, Iguchi A, Sasaki K, Kiyotani C, Koh K, et al. Hematopoietic cell transplantation for chronic granulomatous disease in Japan. Front Immunol. 2020;11:1617. https://doi.org/10.3389/fimmu.2020.01617.

43. Chiesa R, Wang J, Blok H-J, Hazelaar S, Neven B, Moshous D, et al. Hematopoietic cell transplantation in chronic granulomatous disease: a study of 712 children and adults.

44. Blood. 2020;136:1201-11. https://doi.org/10.1182/blood.2020005590.Güngör T, Teira P, Slatter M, Stussi G, Stepensky P, Moshous D, et al. Reduced-intensity conditioning and HLA-matched haemopoietic stem-cell transplantation in patients with chronic granulomatous disease: a prospective multicentre study. Lancet. 2014;383:436-48. https://doi.org/10.1016/S0140-6736(13)62069-3.

45. Osumi T, Tomizawa D, Kawai T, Sako M, Inoue E, Takimoto T, et al. A prospective study of allogeneic transplantation from unrelated donors for chronic granulomatous disease with target busulfan-based 
reduced-intensity conditioning. Bone Marrow Transplant. 2019;54:168-72.

https://doi.org/10.1038/s41409-018-0271-9.

46. Iguchi A, Cho Y, Yabe H, Kato S, Kato K, Hara J, et al. Long-term outcome and chimerism in patients with Wiskott-Aldrich syndrome treated by hematopoietic cell transplantation: a retrospective nationwide survey. Int J Hematol. 2019;110:364-9. https://doi.org/10.1007/s12185-019-02686-y.

47. Umeda K, Adachi S, Horikoshi Y, Imai K, Terui K, Endo M, et al. Allogeneic hematopoietic stem cell transplantation for Chediak-Higashi syndrome. Pediatr Transplant. 2016;20:271-5. https://doi.org/10.1111/petr.12626.

48. Burrows PD, Fischer A. Building networks for immunodeficiency diseases and immunology training. Nat Immunol. 2008;9:1005-7. https://doi.org/10.1038/ni0908-1005.

\section{Tables}

Table 1a: Details of the characteristics of the patients 
Characteristics (Number of patients evaluated)

\begin{tabular}{|c|c|c|c|}
\hline Patient sex $(n=567)$ & & Conditioning $(n=543)$ & \\
\hline Male & $\begin{array}{l}452 \\
(80 \%)\end{array}$ & MAC & $\begin{array}{l}222 \\
(41 \%)\end{array}$ \\
\hline Female & $\begin{array}{l}115 \\
(20 \%)\end{array}$ & RIC & $\begin{array}{l}321 \\
(59 \%)\end{array}$ \\
\hline Age at Diagnosis $(n=552)$ & & No conditioning (included in RIC) & $\begin{array}{l}4 \\
(0.7 \%)^{a}\end{array}$ \\
\hline 0 years & $\begin{array}{l}315 \\
(57 \%)\end{array}$ & GVHD prophylaxis $(n=565)$ & \\
\hline $1 \sim 4$ years & $\begin{array}{l}144 \\
(26 \%)\end{array}$ & Cyclosporine & $\begin{array}{l}213 \\
(38 \%)\end{array}$ \\
\hline $5 \sim 9$ years & $49(9 \%)$ & Tacrolimus & $\begin{array}{l}329 \\
(58 \%)\end{array}$ \\
\hline 10 19 years & $36(7 \%)$ & None & $6(1 \%)$ \\
\hline 20 years & $8(1 \%)$ & Other & $17(3 \%)$ \\
\hline Median years old (range) & $0(0-64)$ & Donor Type $(n=567)$ & \\
\hline Age at HCT $(n=567)$ & & Bone marrow & $\begin{array}{l}382 \\
(67 \%)\end{array}$ \\
\hline 0 years & $\begin{array}{l}100 \\
(18 \%)\end{array}$ & MSD & $\begin{array}{l}116 \\
(21 \%)\end{array}$ \\
\hline 1 4 years & $\begin{array}{l}205 \\
(36 \%)\end{array}$ & MORD & $7(1 \%)$ \\
\hline $5 \sim 9$ years & $89(16 \%)$ & mMORD & $40(7 \%)$ \\
\hline 10 19 years & $\begin{array}{l}115 \\
(20 \%)\end{array}$ & URBM & $\begin{array}{l}219 \\
(39 \%)\end{array}$ \\
\hline $20 \sim$ years & $58(10 \%)$ & Cord blood & $\begin{array}{l}160 \\
(28 \%)\end{array}$ \\
\hline Median years old (range) & $4(0-69)$ & URCB & $\begin{array}{l}157 \\
(28 \%)\end{array}$ \\
\hline Time from diagnosis to HCT $(n=552)$ & & MSD & $2(0.4 \%)$ \\
\hline$\sim 1$ year & $\begin{array}{l}223 \\
(40 \%)\end{array}$ & mMORD & $1(0.2 \%)$ \\
\hline 1 3 years & $\begin{array}{l}112 \\
(20 \%)\end{array}$ & Peripheral blood & $22(4 \%)$ \\
\hline $3 \sim 6$ years & $76(14 \%)$ & MSD & $10(2 \%)$ \\
\hline 6 10years & $42(8 \%)$ & mMORD & $12(2 \%)$ \\
\hline
\end{tabular}




\begin{tabular}{|c|c|c|c|}
\hline 10 years & $99(18 \%)$ & Bone marrow + cord blood (MSD) & $1(0.2 \%)$ \\
\hline Median years (range) & $\begin{array}{l}1.7(0- \\
36.8)\end{array}$ & Peripheral blood + cord blood (MSD) & $1(0.2 \%)$ \\
\hline Year of HCT $(n=567)$ & & $\begin{array}{l}\text { Bone marrow + peripheral blood } \\
(\mathrm{mMORD})\end{array}$ & $1(0.2 \%)$ \\
\hline 1985 2005 & $\begin{array}{l}200 \\
(35 \%)\end{array}$ & Disease category ${ }^{b}(n=567)$ & \\
\hline 2006 2016 & $\begin{array}{l}367 \\
(65 \%)\end{array}$ & Combined immunodeficiency & $48(8 \%)$ \\
\hline $\begin{array}{l}\text { Respiratory impairment at HCT } \\
(n=443)\end{array}$ & & Wiskott-Aldrich syndrome & $\begin{array}{l}118 \\
(21 \%)\end{array}$ \\
\hline Yes & $41(9 \%)$ & Hemophagocytic syndrome & $\begin{array}{l}129 \\
(23 \%)\end{array}$ \\
\hline No & $\begin{array}{l}402 \\
(91 \%)\end{array}$ & Phagocytic cell disorder & $\begin{array}{l}201 \\
(35 \%)\end{array}$ \\
\hline $\begin{array}{l}\text { Bacterial or Fungal Infection at HCT } \\
(n=443)\end{array}$ & & others & $\begin{array}{l}71 \\
(13 \%)\end{array}$ \\
\hline Yes & $95(21 \%)$ & & \\
\hline No & $\begin{array}{l}348 \\
(79 \%)\end{array}$ & & \\
\hline
\end{tabular}

${ }^{a}$ A patient with CHARGE syndrome and 3 patients with Di-George syndrome received unconditioned HCT.

${ }^{\mathrm{b}}$ The details of diagnosis are shown in table $\mathrm{S} 1$.

$\mathrm{HCT}$, Hematopoietic cell transplantation; MAC, myeloablative conditioning; RIC, reduced intensity conditioning; GVHD, graft-versus-host-disease; MSD, matched sibling donor; MORD, matched other related donor; mMORD, mismatched other related donor; URBM, unrelated bone marrow; URCB, unrelated cord blood Table 1b: Details of the diagnosis of the patients according to IUIS 2019 classification 


\begin{tabular}{|c|c|c|c|c|c|}
\hline Patient diagnosis & $\mathbf{N}(\%)$ & $\begin{array}{l}\text { No. of } \\
\text { survivors } \\
\text { (\%) }\end{array}$ & & & $\begin{array}{l}\text { No. of } \\
\text { survivors } \\
\text { (\%) }\end{array}$ \\
\hline $\begin{array}{l}\text { I. Immunodeficiencies } \\
\text { affecting cellular and } \\
\text { humoral immunity }\end{array}$ & $\begin{array}{l}47 \\
(8 \%)\end{array}$ & $37(79 \%)$ & $\begin{array}{l}\text { IV. Diseases of immune } \\
\text { dysregulation }\end{array}$ & $\begin{array}{l}133 \\
(23 \%)\end{array}$ & $91(68 \%)$ \\
\hline $\begin{array}{l}\text { CD40 ligand def. / X-linked } \\
\text { hyper lgM syndrome }\end{array}$ & $\begin{array}{l}39 \\
(7 \%)\end{array}$ & $34(87 \%)$ & $\begin{array}{l}\text { Familial hemophagocytic } \\
\text { lymphohistiocytosis }^{d}\end{array}$ & $\begin{array}{l}101 \\
(18 \%)\end{array}$ & $64(63 \%)$ \\
\hline DOCK8 def. & $\begin{array}{l}1 \\
(0.2 \%)\end{array}$ & $1(100 \%)$ & $\begin{array}{l}\text { Chediak-Higashi } \\
\text { syndrome }^{\mathrm{d}}\end{array}$ & $7(1 \%)$ & $5(71 \%)$ \\
\hline ZAP-70 def. & $\begin{array}{l}1 \\
(0.2 \%)\end{array}$ & $0(0 \%)$ & $X L P 1^{d}$ & $\begin{array}{l}1 \\
(0.2 \%)\end{array}$ & $1(100 \%)$ \\
\hline Bare lymphocyte syndrome & $\begin{array}{l}1 \\
(0.2 \%)\end{array}$ & $1(0 \%)$ & $X L P 2^{d}$ & $\begin{array}{l}10 \\
(2 \%)\end{array}$ & $8(80 \%)$ \\
\hline Unspecified CID & $\begin{array}{l}5 \\
(0.9 \%)\end{array}$ & $1(20 \%)$ & Unspecified XLP & $\begin{array}{l}10 \\
(2 \%)\end{array}$ & $9(90 \%)$ \\
\hline $\begin{array}{l}\text { II. CID with associated or } \\
\text { syndromic features }\end{array}$ & $\begin{array}{l}136 \\
(24 \%)\end{array}$ & $\begin{array}{l}106 \\
(78 \%)\end{array}$ & IPEX syndrome ${ }^{c}$ & $\begin{array}{l}2 \\
(0.4 \%)\end{array}$ & 2 (100\%) \\
\hline $\begin{array}{l}\text { Wiskott-Aldrich syndrome / X- } \\
\text { linked thrombocytopenia }{ }^{b}\end{array}$ & $\begin{array}{l}118 \\
(21 \%)\end{array}$ & $97(82 \%)$ & CTLA4 def. ${ }^{c}$ & $\begin{array}{l}1 \\
(0.2 \%)\end{array}$ & $1(100 \%)$ \\
\hline Hyper lgE syndrome ${ }^{c}$ & $\begin{array}{l}4 \\
(0.7 \%)\end{array}$ & $3(75 \%)$ & IL-10 receptor def. ${ }^{\mathrm{C}}$ & $\begin{array}{l}1 \\
(0.2 \%)\end{array}$ & $1(100 \%)$ \\
\hline DiGeorge syndrome ${ }^{c}$ & $\begin{array}{l}4 \\
(0.7 \%)\end{array}$ & $2(50 \%)$ & $\begin{array}{l}\text { V. Congenital defects of } \\
\text { phagocyte number, } \\
\text { function, or both }\end{array}$ & $\begin{array}{l}201 \\
(35 \%)\end{array}$ & $\begin{array}{l}168 \\
(84 \%)\end{array}$ \\
\hline CHARGE syndrome ${ }^{c}$ & $\begin{array}{l}2 \\
(0.4 \%)\end{array}$ & $0(0 \%)$ & $\begin{array}{l}\text { Chronic granulomatous } \\
\text { disease }^{\mathrm{e}}\end{array}$ & $\begin{array}{l}126 \\
(22 \%)\end{array}$ & $\begin{array}{l}100 \\
(79 \%)\end{array}$ \\
\hline NEMO def. ${ }^{c}$ & $\begin{array}{l}3 \\
(0.5 \%)\end{array}$ & $2(67 \%)$ & $\begin{array}{l}\text { Severe congenital } \\
\text { neutropenia }^{\mathrm{e}}\end{array}$ & $\begin{array}{l}60 \\
(11 \%)\end{array}$ & $55(92 \%)$ \\
\hline $\begin{array}{l}\text { EDA-ID due to IKBA GOF } \\
\text { mutation }^{c}\end{array}$ & $\begin{array}{l}2 \\
(0.4 \%)\end{array}$ & $0(0 \%)$ & $\begin{array}{l}\text { Leukocyte adhesion } \\
\text { deficiency }\end{array}$ & $6(1 \%)$ & $6(100 \%)$ \\
\hline Unspecified EDA-IDC & $\begin{array}{l}2 \\
(0.4 \%)\end{array}$ & $2(100 \%)$ & $\begin{array}{l}\text { Shwachman-Diamond } \\
\text { syndrome }^{\mathrm{e}}\end{array}$ & $\begin{array}{l}5 \\
(0.9 \%)\end{array}$ & $3(60 \%)$ \\
\hline $\begin{array}{l}\text { Purine nucleoside } \\
\text { phosphorylase def.c }\end{array}$ & $\begin{array}{l}1 \\
(0.2 \%)\end{array}$ & $0(0 \%)$ & $\begin{array}{l}\text { MonoMAC syndrome / } \\
\text { GATA2 def. }\end{array}$ & $\begin{array}{l}4 \\
(0.7 \%)\end{array}$ & $4(100 \%)$ \\
\hline $\begin{array}{l}\text { Ill. Predominantly antibody } \\
\text { deficiencies }\end{array}$ & $\begin{array}{l}21 \\
(4 \%)\end{array}$ & $16(76 \%)$ & $\begin{array}{l}\text { VI. Defects in intrinsic and } \\
\text { innate immunity }\end{array}$ & $7(1 \%)$ & $3(43 \%)$ \\
\hline $\begin{array}{l}\text { Common variable } \\
\text { immunodeficiency }\end{array}$ & $\begin{array}{l}13 \\
(2 \%)\end{array}$ & $10(77 \%)$ & $\begin{array}{l}\text { Chronic mucocutaneous } \\
\text { candidiasis }^{c}\end{array}$ & $\begin{array}{l}4 \\
(0.7 \%)\end{array}$ & $0(0 \%)$ \\
\hline
\end{tabular}




\begin{tabular}{|c|c|c|c|c|c|}
\hline $\begin{array}{l}\text { Hyper IgM syndrome other } \\
\text { than CD } 40 \mathrm{~L} \text { def. }{ }^{\mathrm{C}}\end{array}$ & $\begin{array}{l}4 \\
(0.7 \%)\end{array}$ & $4(100 \%)$ & WHIM syndrome ${ }^{\mathrm{c}}$ & $\begin{array}{l}3 \\
(0.5 \%)\end{array}$ & $3(100 \%)$ \\
\hline $\begin{array}{l}\text { Activated PI3K delta } \\
\text { syndrome }^{\mathrm{c}}\end{array}$ & $\begin{array}{l}3 \\
(0.5 \%)\end{array}$ & $2(67 \%)$ & IX. Bone marrow failure & $\begin{array}{l}22 \\
(4 \%)\end{array}$ & $16(73 \%)$ \\
\hline $\begin{array}{l}\text { X-linked } \\
\text { agammaglobulinemia }^{c}\end{array}$ & $\begin{array}{l}1 \\
(0.2 \%)\end{array}$ & $0(100 \%)$ & Dyskeratosis con & $\begin{array}{l}22 \\
(4 \%)\end{array}$ & $16(73 \%)$ \\
\hline
\end{tabular}

aThese diseases were classified as "combined immunodeficiency" in this study.

'Two patients were registered as "X-linked thrombocytopenia" in the TRUMP and classified as "WAS" in this study.

"These diseases were classified as "others" in this study.

${ }^{\text {d}}$ These diseases were classified as "hemophagocytic syndrome" in this study.

eThese diseases were classified as "phagocytic cell disorder" in this study.

No., number; def., deficiency; CID, combined immunodeficiency; XLP, X-linked lymphoproliferative disease; EDA-ID, Anhidrotic ectodermal dysplasia with Immunodeficiency; GOF, gain of function

Table 2: Transplant outcomes over the whole period 


\begin{tabular}{|c|c|}
\hline Outcome (Number of patients evaluated) & Overall \\
\hline \multicolumn{2}{|l|}{ Overall survival $(\%)(n=567)$} \\
\hline 1 year $(95 \% \mathrm{Cl})$ & $84(80-87)$ \\
\hline 5 year $(95 \% \mathrm{Cl})$ & $77(73-81)$ \\
\hline 10 year $(95 \% \mathrm{Cl})$ & $74(69-78)$ \\
\hline 25 year $(95 \% \mathrm{Cl})$ & $72(66-76)$ \\
\hline \multicolumn{2}{|l|}{ Event-free survival $(\%)(n=567)$} \\
\hline 1 year $(95 \% \mathrm{Cl})$ & $79(75-82)$ \\
\hline 5 year $(95 \% \mathrm{Cl})$ & $70(65-73)$ \\
\hline 10 year $(95 \% \mathrm{Cl})$ & $64(60-69)$ \\
\hline 25 year $(95 \% \mathrm{Cl})$ & $62(57-67)$ \\
\hline \multicolumn{2}{|l|}{ Neutrophil recovery $(n=554)$} \\
\hline Cumulative incidence $(\%)$ at 30 days $(95 \% \mathrm{Cl})$ & $88(85-91)$ \\
\hline Cumulative incidence $(\%)$ at 60 days $(95 \% \mathrm{Cl})$ & $92(89-94)$ \\
\hline Median days of recovery (range) & $17(0-130)$ \\
\hline \multicolumn{2}{|l|}{ Platelet recovery $(n=527)$} \\
\hline Cumulative incidence $(\%)$ at 30 days $(95 \% \mathrm{Cl})$ & $37(33-41)$ \\
\hline Cumulative incidence $(\%)$ at 60 days $(95 \% \mathrm{Cl})$ & $69(65-73)$ \\
\hline Median days of recovery (range) & $32(0-356)$ \\
\hline \multicolumn{2}{|l|}{ Retransplantation $(n=567)$} \\
\hline Cumulative incidence $(\%)$ at 10 years $(95 \% \mathrm{Cl})$ & $13(10-17)$ \\
\hline Median days of retransplantation (range) & $177(20-2,945)$ \\
\hline \multicolumn{2}{|l|}{ Acute GVHD grade II-IV ( $n=556)$} \\
\hline Cumulative incidence $(\%)$ at 1 year $(95 \% \mathrm{Cl})$ & $26(22-29)$ \\
\hline \multicolumn{2}{|l|}{ Chronic GVHD $(n=491)$} \\
\hline Cumulative incidence $(\%)$ at 2 years $(95 \% \mathrm{Cl})$ & $20(16-23)$ \\
\hline
\end{tabular}

aLogrank test; ${ }^{\mathrm{b}}$ Gray's test

$\mathrm{Cl}$, confidence interval; NA, not applicable; GVHD, graft-versus-host disease

Table 3: Factors affecting overall survival and event-free survival after HCT in 2006-2016 


\begin{tabular}{|c|c|c|c|c|c|c|c|c|c|}
\hline \multirow[t]{3}{*}{ Factors } & \multirow[t]{3}{*}{$\mathrm{n}$} & \multicolumn{4}{|c|}{ Overall survival } & \multicolumn{4}{|c|}{ Event-free survival } \\
\hline & & \multicolumn{2}{|c|}{$\begin{array}{l}\text { Univariate } \\
\text { analysis }\end{array}$} & \multicolumn{2}{|c|}{$\begin{array}{l}\text { Multivariate } \\
\text { analysis }\end{array}$} & \multicolumn{2}{|c|}{$\begin{array}{l}\text { Univariate } \\
\text { analysis }\end{array}$} & \multicolumn{2}{|c|}{$\begin{array}{l}\text { Multivariate } \\
\text { analysis }\end{array}$} \\
\hline & & $\begin{array}{l}5- \\
\text { year } \\
(95 \% \\
\text { Cl) }\end{array}$ & $\begin{array}{l}P \\
\text { value }\end{array}$ & $\begin{array}{l}\mathrm{HR} \\
(95 \% \\
\mathrm{Cl})\end{array}$ & $\begin{array}{l}P \\
\text { value }\end{array}$ & $\begin{array}{l}5- \\
\text { year } \\
(95 \% \\
\text { Cl) }\end{array}$ & $\begin{array}{l}P \\
\text { value }\end{array}$ & $\begin{array}{l}\mathrm{HR}(95 \% \\
\mathrm{Cl})\end{array}$ & $\begin{array}{l}P \\
\text { value }\end{array}$ \\
\hline Donor Type & & & 0.046 & & & & $\begin{array}{l}< \\
0.001\end{array}$ & & \\
\hline MSD & 70 & $\begin{array}{l}84 \% \\
(72- \\
91 \%)\end{array}$ & & 1 & & $\begin{array}{l}81 \% \\
(69- \\
89 \%)\end{array}$ & & 1 & \\
\hline URCB & 104 & $\begin{array}{l}71 \% \\
(61- \\
79 \%)\end{array}$ & & $\begin{array}{l}1.8 \\
(0.8- \\
3.8)\end{array}$ & 0.13 & $\begin{array}{l}56 \% \\
(45- \\
65 \%)\end{array}$ & & $\begin{array}{l}2.7(1.4- \\
5.2)\end{array}$ & 0.003 \\
\hline ORD & 26 & $\begin{array}{l}68 \% \\
(42- \\
84 \%)\end{array}$ & & $\begin{array}{l}1.7 \\
(0.7- \\
4.7)\end{array}$ & 0.27 & $\begin{array}{l}53 \% \\
(31- \\
71 \%)\end{array}$ & & $\begin{array}{l}2.7(1.2- \\
6.1)\end{array}$ & 0.02 \\
\hline URBM & 167 & $\begin{array}{l}83 \% \\
(76- \\
89 \%)\end{array}$ & & $\begin{array}{l}1.1 \\
(0.5- \\
2.2)\end{array}$ & 0.87 & $\begin{array}{l}77 \% \\
(69- \\
83 \%)\end{array}$ & & $\begin{array}{l}1.1(0.6- \\
2.1)\end{array}$ & 0.72 \\
\hline $\begin{array}{l}\text { Respiratory } \\
\text { impairment at } \\
\text { HCT }\end{array}$ & & & 0.005 & & & & 0.05 & & \\
\hline No & 326 & $\begin{array}{l}81 \% \\
(76- \\
85 \%)\end{array}$ & & 1 & & $\begin{array}{l}72 \% \\
(66- \\
77 \%)\end{array}$ & & 1 & \\
\hline Yes & 36 & $\begin{array}{l}64 \% \\
(45- \\
78 \%)\end{array}$ & & $\begin{array}{l}2.3 \\
(1.2- \\
4.2)\end{array}$ & 0.01 & $\begin{array}{l}58 \% \\
(39- \\
73 \%)\end{array}$ & & $\begin{array}{l}1.5(0.8- \\
2.6)\end{array}$ & 0.18 \\
\hline Disease category & & & 0.003 & & & & 0.07 & & \\
\hline $\begin{array}{l}\text { Wiskott-Aldrich } \\
\text { syndrome }\end{array}$ & 58 & $\begin{array}{l}89 \% \\
(77- \\
95 \%)\end{array}$ & & 1 & & $\begin{array}{l}82 \% \\
(69- \\
90 \%)\end{array}$ & & 1 & \\
\hline $\begin{array}{l}\text { Combined } \\
\text { immunodeficiency }\end{array}$ & 28 & $\begin{array}{l}84 \% \\
(63- \\
94 \%)\end{array}$ & & $\begin{array}{l}1.4 \\
(0.4- \\
5.0)\end{array}$ & 0.6 & $\begin{array}{l}73 \% \\
(51- \\
86 \%)\end{array}$ & & $\begin{array}{l}1.5(0.6- \\
4.0)\end{array}$ & 0.39 \\
\hline $\begin{array}{l}\text { Hemophagocytic } \\
\text { syndrome }\end{array}$ & 82 & $\begin{array}{l}70 \% \\
(59- \\
79 \%)\end{array}$ & & $\begin{array}{l}3.1 \\
(1.3- \\
7.7)\end{array}$ & 0.01 & $\begin{array}{l}63 \% \\
(50- \\
73 \%)\end{array}$ & & $\begin{array}{l}2.1 \\
(0.9997- \\
4.3)\end{array}$ & 0.05 \\
\hline $\begin{array}{l}\text { Phagocytic } \\
\text { disorder }\end{array}$ & 147 & $\begin{array}{l}82 \% \\
(73- \\
88 \%)\end{array}$ & & $\begin{array}{l}1.7 \\
(0.7- \\
4.3)\end{array}$ & 0.26 & $\begin{array}{l}70 \% \\
(60- \\
77 \%)\end{array}$ & & $\begin{array}{l}2.1 \\
(1.04- \\
4.4)\end{array}$ & 0.04 \\
\hline Others & 52 & $70 \%$ & & 2.7 & 0.049 & $64 \%$ & & $2.4(1.1-$ & 0.03 \\
\hline
\end{tabular}


$\mathrm{HCT}$, hematopoietic cell transplantation; $\mathrm{Cl}$, confidence interval; $\mathrm{HR}$, hazard ratio; $\mathrm{MSD}$, matched sibling donor; URCB, unrelated cord blood; ORD, other related donor; URBM, unrelated bone marrow.

Table 4: Transplant-associated complications 


\begin{tabular}{|c|c|c|c|c|c|}
\hline Infection & $\mathrm{n}(\%)$ & $\begin{array}{l}\text { Number of } \\
\text { patients } \\
\text { evaluated }\end{array}$ & Non-Infection & $\mathrm{n}(\%)$ & 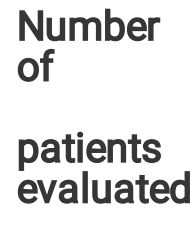 \\
\hline CMV antigenemia & $\begin{array}{l}125 \\
(29 \%)\end{array}$ & 436 & $\begin{array}{l}\text { Central nervous system } \\
\text { disorder }\end{array}$ & $\begin{array}{l}28 \\
(5 \%)\end{array}$ & 542 \\
\hline CMV infection & $25(6 \%)^{a}$ & 453 & Hemorrhage & $\begin{array}{l}27 \\
(5 \%)\end{array}$ & 542 \\
\hline Pneumonia & $6(1 \%)^{\mathrm{a}}$ & 453 & $\begin{array}{l}\text { Thrombotic } \\
\text { microangiopathy }\end{array}$ & $\begin{array}{l}27 \\
(5 \%)\end{array}$ & 542 \\
\hline Hepatitis & $\begin{array}{l}3 \\
(0.7 \%)^{\mathrm{a}}\end{array}$ & 453 & Veno-occlusive disease & $\begin{array}{l}20 \\
(4 \%)\end{array}$ & 542 \\
\hline Enterocolitis & $9(2 \%)^{a}$ & 453 & $\begin{array}{l}\text { Interstitial pneumonitis } \\
\text { (Non-Infectious) }\end{array}$ & $\begin{array}{l}14 \\
(3 \%)\end{array}$ & 542 \\
\hline Retinitis & $\begin{array}{l}2 \\
(0.4 \%)^{\mathrm{a}}\end{array}$ & 453 & ARDS & $\begin{array}{l}12 \\
(2 \%)\end{array}$ & 542 \\
\hline Urinary tract infection & $\begin{array}{l}2 \\
(0.4 \%)^{\mathrm{a}}\end{array}$ & 453 & Post-HCT HLH & $\begin{array}{l}11 \\
(2 \%)\end{array}$ & 542 \\
\hline Meningitis & $\begin{array}{l}1 \\
(0.2 \%)^{a, b}\end{array}$ & 453 & $\mathrm{BO}$ & $6(1 \%)$ & 542 \\
\hline Other viral infection & $\begin{array}{l}84 \\
(19 \%)^{a}\end{array}$ & 449 & BOOP & $\begin{array}{l}2 \\
(0.4 \%)\end{array}$ & 542 \\
\hline EBV & $33(7 \%)^{a}$ & 449 & Cardiac failure & $6(1 \%)$ & 542 \\
\hline $\begin{array}{l}\text { Human polyomavirus } 1 \\
\text { (BK virus) }\end{array}$ & $18(4 \%)^{\mathrm{a}}$ & 449 & Hemolytic anemia & $\begin{array}{l}5 \\
(0.9 \%)\end{array}$ & 542 \\
\hline VZV & $15(3 \%)^{a}$ & 449 & Pancreatitis & $\begin{array}{l}4 \\
(0.7 \%)\end{array}$ & 542 \\
\hline HHV6 & $9(2 \%)^{a}$ & 449 & Malignancy & $\begin{array}{l}14 \\
(3 \%)\end{array}$ & 545 \\
\hline Norovirus & $6(1 \%)^{\mathrm{a}}$ & 449 & PTLD & $\begin{array}{l}12 \\
(2 \%)\end{array}$ & 545 \\
\hline HSV & $\begin{array}{l}3 \\
(0.7 \%)^{\mathrm{a}}\end{array}$ & 449 & DLBCL & $\begin{array}{l}1 \\
(0.2 \%)\end{array}$ & 545 \\
\hline Adenovirus & $\begin{array}{l}3 \\
(0.7 \%)^{\mathrm{a}}\end{array}$ & 449 & Osteosarcoma & $\begin{array}{l}1 \\
(0.2 \%)\end{array}$ & 545 \\
\hline $\begin{array}{l}\text { Human polyomavirus } 2 \\
\text { (JC virus) }\end{array}$ & $\begin{array}{l}2 \\
(0.4 \%)^{\mathrm{a}}\end{array}$ & 449 & Short stature $(\leq-2 S D)$ & $\begin{array}{l}74 \\
(19 \%)\end{array}$ & 381 \\
\hline Influenza A virus / RSV & 1 & 449 & Gonadal dysfunction & 20 & 168 \\
\hline
\end{tabular}




\begin{tabular}{|c|c|c|c|c|c|}
\hline $\begin{array}{l}\text { / } \\
\text { parainfluenza virus / } \\
\text { Coxsackievirus }\end{array}$ & $(0.2 \%)^{a, b}$ & & & $(12 \%$ & \\
\hline Fungal infection & $\begin{array}{l}62 \\
(12 \%)^{a}\end{array}$ & 525 & Hypothyroidism & $\begin{array}{l}11 \\
(4 \%)\end{array}$ & 285 \\
\hline Candidiasis & $\begin{array}{l}4 \\
(0.8 \%)^{a}\end{array}$ & 525 & & & \\
\hline Aspergillosis (definitive) & $30(6 \%)^{a}$ & 525 & & & \\
\hline $\begin{array}{l}\text { Aspergillosis } \\
\text { (suspected) }\end{array}$ & $20(4 \%)^{a}$ & 525 & & & \\
\hline $\begin{array}{l}\text { Unspecified fungal } \\
\text { infection }\end{array}$ & $11(2 \%)^{a}$ & 525 & & & \\
\hline Bacterial infection & $\begin{array}{l}172 \\
(38 \%)^{a}\end{array}$ & 452 & & & \\
\hline
\end{tabular}

aThe patients whose infection was diagnosed before and after transplantation are included.

${ }^{\mathrm{b}}$ The number (and the percentage) of each item is shown.

CMV, cytomegalovirus; EBV, Epstein-Barr virus; VZV, varicella zoster virus; HHV6, human herpesvirus 6; HSV, herpes simplex virus; RSV, respiratory syncytial virus; ARDS, acute respiratory distress syndrome; HCT, hematopoietic cell transplantation; $\mathrm{HLH}$, hemophagocytic lymphohistiocytosis; $\mathrm{BO}$, bronchiolitis obliterans; BOOP, bronchiolitis obliterans organizing pneumonia; PTLD, post-transplant lymphoproliferative disorder; DLBCL, diffuse large B-cell lymphoma; SD, standard deviation

\section{Table 5: Causes of death}




\begin{tabular}{|c|c|}
\hline Cause of death & $\mathrm{n}(\%)$ \\
\hline Infection & $43(33 \%)$ \\
\hline Non-Infection & $88(67 \%)$ \\
\hline Pulmonary (non-infection) & $33(25 \%)$ \\
\hline Others (non-infection) & $55(42 \%)$ \\
\hline Hemorrhage & $8(6 \%)$ \\
\hline Multi-organ failure & $8(6 \%)$ \\
\hline Liver failure & $5(4 \%)$ \\
\hline Cardiac failure / cardiomyopathy & $4(3 \%)$ \\
\hline Thrombotic microangiopathy & $4(3 \%)$ \\
\hline Acute GVHD & $4(3 \%)$ \\
\hline Chronic GVHD & $4(3 \%)$ \\
\hline Secondary malignancy & $3(2 \%)$ \\
\hline Renal failure & $2(2 \%)$ \\
\hline CNS dysfunction & $2(2 \%)$ \\
\hline Veno-occlusive disease & $2(2 \%)$ \\
\hline Hemophagocytic syndrome & $2(2 \%)$ \\
\hline EBV-LPD & $1(1 \%)$ \\
\hline Pancreatitis & $1(1 \%)$ \\
\hline Unknown & $5(4 \%)$ \\
\hline Total & 131 \\
\hline
\end{tabular}

GVHD, graft-versus-host disease; CNS, central nervus system; EBV-LPD, Epstein Barr virus associated lymphoproliferative disorder.

\section{Figures}




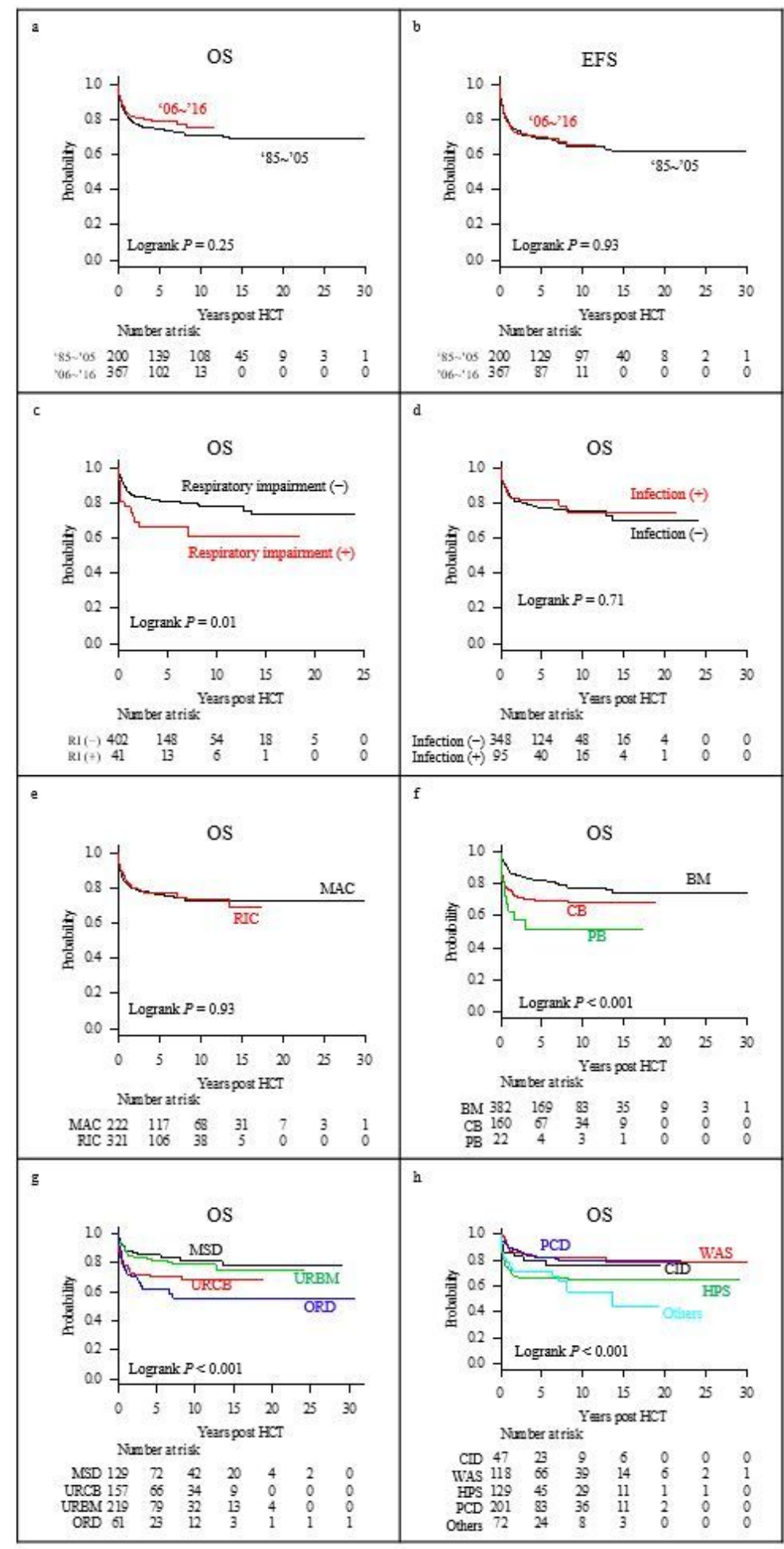

Figure 1

Kaplan-Meier survival curves (a) OS and (b) EFS according to the period in which HCT was performed. The subsequent analyses for OS were applied to the patients in all the periods, according to (c) RI at HCT, (d) the presence of bacterial and fungal infection at HCT, (e) conditioning regimens, (f) donor source, (g) donor type, and (h) disease category. OS, overall survival; HCT, hematopoietic cell transplantation; EFS, event-free survival; RI, respiratory impairment; MAC, myeloablative conditioning; RIC, reduced-intensity conditioning; BM, bone marrow; CB, cord blood; PB, peripheral blood; MSD, matched sibling donor; URCB, unrelated cord 
blood; URBM, unrelated bone marrow; ORD, other related donor; CID, combined immunodeficiency; WAS, Wiskott-Aldrich syndrome; HPS, hemophagocytic syndrome; PCD, phagocytic disorder.

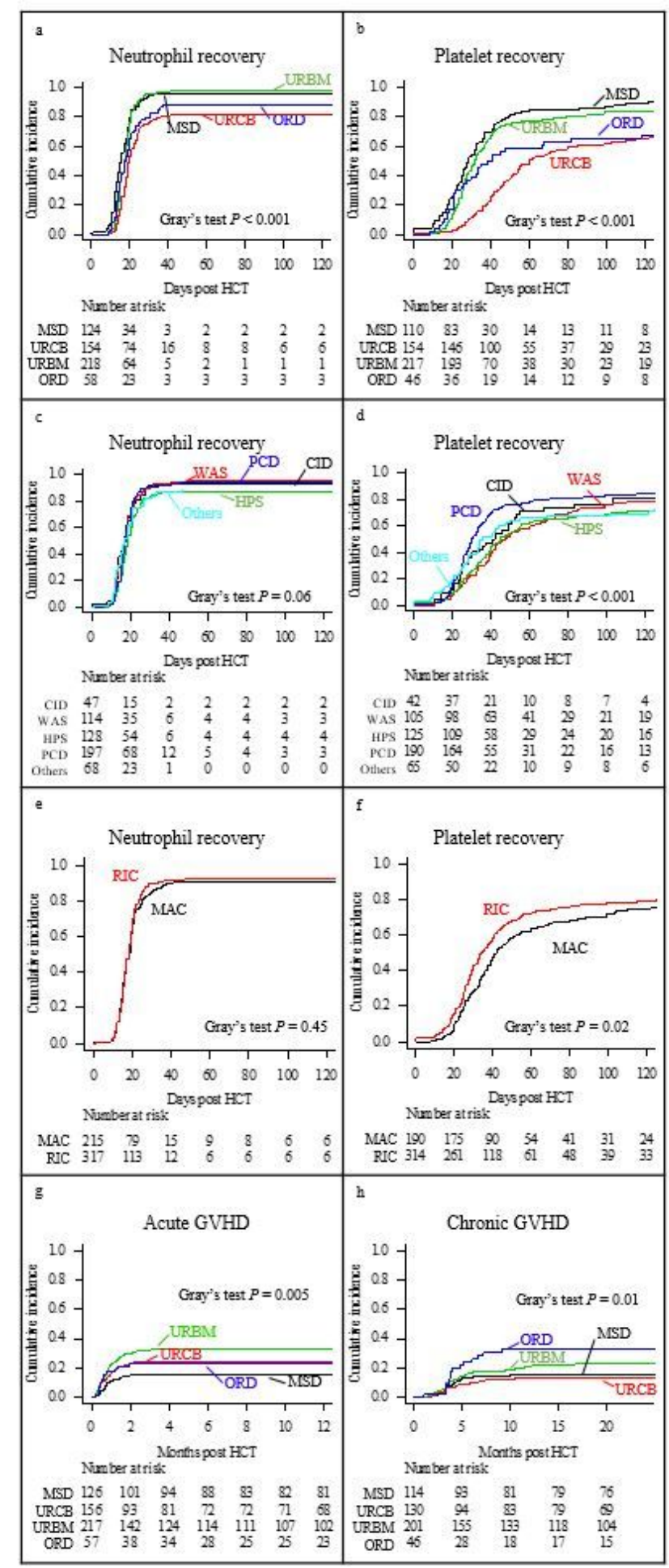

\section{Figure 2}

Cumulative incidence of hematologic recovery and graft-versus-host disease The cumulative incidences of neutrophil recovery and platelet recovery according to ( $a$ and b, respectively) donor type, ( $c$ and $d$, respectively) disease category, and (e and $f$, respectively) conditioning regimen are shown. The patients who received no conditioning were excluded from these analyses. The cumulative incidences of (g) grade II-IV 
acute GVHD and (h) chronic GVHD according to donor type are also shown. HCT, hematopoietic cell transplantation; MSD, matched sibling donor; URCB, unrelated cord blood; URBM, unrelated bone marrow; ORD, other related donor; CID, combined immunodeficiency; WAS, Wiskott-Aldrich syndrome; HPS, hemophagocytic syndrome; PCD, phagocytic disorder; MAC, myeloablative conditioning; RIC, reducedintensity conditioning; GVHD, graft-versus-host disease.

\section{Supplementary Files}

This is a list of supplementary files associated with this preprint. Click to download.

- LanguageEditingCertificate.pdf

- electronicsupplementalmaterial.docx 